\title{
The Joint Cultural Heritage and Civilization of Iran and Kazakhstan: Customs and Ceremonies
}

\author{
Keyhan Shahriyari \\ Farhangian University, Shiraz, Iran
}

The customs and ceremonies are an ancient historic process. Most of customs and ceremonies have arisen before formation of a nation and for this reason they are assumed commonly as important for several nations. Of course, any ethnicity possesses the specific norms and habits per se and it is still kept as a certain symbol of the given nation. The custom and tradition are created and formed according to lifestyle, belief, and idea and ideology of tribes and transferred from one generation to the next generation and then conveyed, transformed, and acquires new form. What is not adaptable to the new social relations is destroyed and what it requires for the life develops and acquires new meaning. The presence of common customs and ceremonies is strongly related to the links between tribes and nations and no custom or ceremony can be found that is peerless and unique among tribes and nations. The national presence and identity is a sustainable phenomenon that appears from human's conduct and behavior and the national conduct is characterized and revealed by special warm-up of that nation and their intellectual spirit and attributes. There are two narrations about Kazakhs: (1) According to manuscript from Herodotus, at the 6th century BC some people were living in geographical zones of Gorgan, Gonbad Kavoos, and Turkmen Plain, who were called Daha or Dahae (Dahae or Daha). It seems that they were Scythian tribes, who were inhabited at north of Gorgan and Khorasan and the scope of their dominance was continued in Transoxania and central Ural region and central Asia. This tribe gradually rushed into Iran and integrated with all ethnicities and races that were living in Gorgan; and (2) According to national Kazakh encyclopedia (vol. II), Adai is one of Kazakh tribes, which are divided into seven groups, were inhabited in western Kazakhstan on Mangyshlak Peninsula with capital Aktau and due to the calamities and disasters occurred during Stalin's dictatorship era, some of them were migrating to Iran. This event took place in 1934 AD (or 1313 Iranian calendar year). The name of Adai has been mentioned in some historic sources as Dai or Dahae. It can be perceived from the above-said issues that the relationship between Kazakhs and particularly Adais with Iranians is deep-rooted in fathoms of history. For this reason, there are some commonalities in customs and traditions of Iranian nation at cities such as Gorgan, Gonbad, and Turkmen port with the customs and traditions of Kazakhstan people that such commonalities have been increased further with appearance of Islam and accepting it in Iran and Kazakhstan. The customs and traditions of Kazakhs are divided into three groups: (1) The customs and rites for training the children; (2) The customs and traditions for living and sustenance; and (3) The cultural customs and ceremonies such as national and religious feasts and ceremonies for weddings, etc. As a result, in this article, it has been tried to examine some of these cultural commonalities among Iran and Kazakhstan.

Keywords: Kazakh, Dahae, Gorgan, Turkmen

Keyhan Shahriyari, Ph. D. candidate, Lecturer, Department of Persian Literature, Farhangian University. 


\section{Introduction}

Iranian people have many old traditions which, in spite of many centuries passed and hundreds of wars occurred, are still common and evolve with great power. These traditions are the greatest links of social solidarity among Iranians. These traditions, along with other amazing works and resources of an ancient nation, are remains of their national identity. Customs and traditions are created and transformed from one to the next generation. Sometimes, they change and are replenished in new ways. The common aspects of traditions are closely related to the connections between different nations and no tradition can be found to be unique just to one particular group. These cultural commonalities are more observable among those nations which have historical and ancient relations. This study aims to introduce these cultural commonalities between Iran and Kazakhstan. First, the historical and ethnical bonds between Kazakhs in Iran and Kazakhstan will be examined. Then the shared cultural values and customs among them will be introduced.

\section{Significance of the Study}

Addressing the cultural commonalities of various ethnicities and nations has been taken into consideration over the history and this has caused the researchers to pay attention to this issue. Kazakhstan is located at neighborhood of Iran and due to symbiosis with the Iranians, who are inhabitant at the northern regions of Iran; it possesses some common cultural features so it is duly to conduct study in this regard.

It has been tried in this investigation to give answers to the questions and then to analyze them; for instance:

Who were Dahae people and where did they live? Why they migrated to Iran? How were they intermingled with Iranian tribes? How are the relations between Iran and Kazakhstan? What are some of cultural commonalities between Kazakhs and Iranians?

\section{Background}

Some historians such as Herodotus, Strabone, and Joseph Volesky have written some articles about historical perspectives of Iran and Kazakhstan and of the contemporary writers and groups, who have also worked in this field; one can refer to Fariba Ulum Yazdi, the touristic group of Zanjan Tebyan website ${ }^{1}$, and Seyed Mohammad Kalantari, etc.

It has been tried in the current research to deal with the genealogy of Kazakhs, their habitat, the reason for their immigration to Iran, and some of their customs, rites, and superstitions as possible and at the same time it is referred to their great figures in sciences and literature. Furthermore, we intend to refer to Farabi as well because his birthplace was Kazakhstan and he is considered as their honorary characters there.

Customs and traditions are an ancient historical process. Most of customs and ceremonies had arisen before formation of a nation and for this reason they are deemed commonly important for several nations. Of course, any ethnicity possesses its own specific customs and habits and they are preserved as the special symbol for the given people. The custom and tradition are formed according to the given lifestyle, belief, paradigms, and ideology of tribes and it is transferred from one generation to another and transformed and acquires new form. What is not adaptable to new social relations is eliminated and what it deemed as necessary for living develops and achieves a new meaning and concept. The common aspects of customs and ceremonies are firmly

\footnotetext{
${ }^{1}$ Retrieved from http://tebyan-az.ir/turism.html
} 
related with links between tribes and nations and no customs and ceremonies can be found as unique and peerless among tribes and nations. The national presence and identity is a sustainable phenomenon that is revealed in human's conduct and behavior and the national conduct is characterized and disclosed with specific warm-up that nation and their spirit and intellectual characteristics.

There are two narrations about Kazakhs: According to historic writing from Herodotus, some people were living in geographical zones of Gorgan, Gonbad Kavoos, and Turkmen Plain at 6th century BC that they were called Daha or Dahae. It seems that they were a group of Scythians (Sakae) that this tribe were dwelling at north Gorgan and Khorasan regions and the scope of dominion was continued in Transoxania, Ural region, and Central Asia. This tribe gradually rushed toward Iran and they were intermingled with some other races living in Gorgan. (Losinski, 2001; Niknejad, 2003)

According to National Kazakh Encyclopedia, second volume, Adai tribe is one of the Kazakh tribes, which are divided into seven genera and they were living at western Kazakhstan in Mangyshlak Peninsula at capital Aktau and due to the calamities and crimes occurred during Stalin's despotic rule, some of them migrated to Iran. This event took place in 1934AD (or 1313 Iranian calendar year). Term “Adai” has been mentioned as "Daha" and "Dahae" in some historic sources (National Kazak, vol. 2).

It can be inferred from the above-said issue that the relationship between Kazakhs and Iranian and especially Adais are deep-rooted in depths of history. Thus, there is no reason for surprise that we can witness the intimate welcoming of Turkmens and Persian people in Golestan province to the latest Kazakh immigrants in this region. Adai people not only have not been assumed as aliens by the local inhabitants, but also Turkmens have accommodated for them as "Belish" (familiar) and the Persians as "acquainted" (Niknejad, 2003, p. 85).

Since the time when Dahae people developed Arsacid Dynasty (Parthian) for establishment of kingdom with leadership of Persia freedom-seeking movement, they have been so far assumed as the major cornerstones for Iranian nation. However, during these vicissitudes, the Arsacid Dynasty was substituted with Sassanid, as they fought with the foreign enemies in Iranian queue, one could ensure that they welcomed the rescuing message of Islam along with their own compatriots and to protest against the corruption in Sassanid Empire. The globe of history continued its path so that with ruining of Qajar Kingdom, a colonel from brigade of Kazakhs laid foundation for the last monarchical dynasty in Iran with claiming for Arsacid ethnicity and under title of Reza Shah Pahlavi and at this time the aforesaid person compelled a group of Dahae descendants that was called "Adai" to leave their ancestral land. This group underwent a lot of oppressions and slaveries. Anyway, 70 years have currently passed from this event and several years were past after independence of Kazakhstan and Iran was one of the first governments, which recognized officially their countries happily and freedom of the Muslim nations in Central Asia.

The Kazakhstan government tends to compensate for the existing imbalance by invitation of Kazakhs, who are disseminated in the adjacent countries and otherwise so Iran allowed that anyone of Iranian Kazakhs and the afghan asylum-seekers of Kazakhs, who are inclined to go to Kazakhstan, to acquire nationality of Kazakhstan.

\section{The Common Aspects of Iran and Kazakhstan}

The Iranian Kazakhs are deemed as the major historical and social commonalities in Iran and Kazakhstan. Regarding the cultural commonalities between Kazakhs and other Iranians, one can refer to their customs and 
ceremonies, including Norouz (New Year Holiday) and the religious feast such as Eid-Al-Adha, and feast for birthday of Islamic Holy Prophet (PBUH), birthday festival, circumcision ceremony, betrothal, and wedding, funerals, and reciting Fateha Sura and alms giving concerning the obituary ceremonies at 3rd, 7th, and 40th days after decease and yearly anniversary for the dead that are held similarly in both countries.

The cultural and social and religious commonalities have caused prevalence of common social, cultural, and religious terms and as a result one can find about 6,000 common words and terms in 10 volume thesaurus of Kazakh language among 60,000 entries in which there are 2,000 Persian words. Some words, which have entered in Kazakh language through literature include God, prophet, Imam, prayer and fasting, ablution, marriage, religion and belief, brother, school, paradise and hell, angel, and king etc.

"Abay”, as a reformist and modernist Kazakh poet, has assumed Firdausi, Hafez, Saadi, Molavi, and Ali-Shir Nava'i as his teachers and asked their pure soul for help.

Abu Nasr Farabi, a great philosopher, hakim, and mathematician, was born in Kazakhstan and he is considered as one of the greatest honorary figures in Kazakhstan. Title of the greatest National Kazakhstan University has been decorated with his name and one of paper bill has been inscribed with his image in this country.

The customs and ceremonies of Kazakhs can be divided into three classes: (1) Customs and rites for training of children such as nomination, ceremonies of 40 days, and circumcision etc.; (2) Customs and traditions for living including national cuisine and outfit, animal husbandry and farming, and fishing etc.; and (3) Cultural and social customs and rites such as music, national and religious feasts, and funeral ceremonies, and even superstitions

According to archeological perspective, the Kazakhstan region has been a habitat of Scythian or Sakae tribe for several years out of which the Iranian roaming tribes are considered as their constituent elements.

The cultural development occurred in the current Kazakhstan and Kirgizstan regions with entrance of Sogdians. The artifacts found in "Pazyryk" zone at Eastern Altai Mountain that signifies the samples of Iranian art reflects this fact that Persian culture has passed through the current region at Kazakhstan since Achaemenid period and gone beyond the Altai region. The intermingling of Persian and Kazakh culture and urbanity over long centuries and their impact on each other can be assumed as a cultural bridge that was built by the Karluk Tribe considered as the most influential Turk tribe at southern region of Kazakhstan and Sogdians as the local Persians in Transoxania.

With reference to historical and cultural sources, we may notice that there has been cultural relationship among Iran and Kazakhstan since ancient era. These two countries have distinctive culture and either of them possesses its own specific culture and never imitates other. These two countries are placed within similar framework by appearance of Islam. In fact, acceptance of Islam was lead to cultural transformation in both of these countries and religious terms entered into the Kazakh language via Persian concepts.

Likewise, this country has been familiar with Persian precious heritage through translation of Persian literary works such as the works of Roodaki, Firdausi, Nezami, Omar Khayyam, Molavi, Saadi and Hafez. Similarly, The Kazakhstan people have noticed the cultural similarities between Persian and Kazakhstan with these translated works; for example, the Norouz Feast is popular in both countries.

Norouz Feast was popular in Iran since pre-Islamic era and its ceremonies have been transferred from Iran to the countries at Central Asia and Kazakhstan (Ghirishman, 1991, p. 46). 
Within Iranian eternal range, Norouz Ceremony includes several days for which we entirely wait and commemoration of these days is deemed as precious and sacred for us. Norouz comes with spring and this feature has particularly validated it. With coming Norouz, this is not only the nature that revives, but also people acquire fresh spirit along with Norouz in several lands such as Iran and Kazakhstan.

The Kazakh people believe that the celestial stars reach to their start point at this day. According to their belief, Norouz is a day when abundance and blessing comes to earth and it is a day when the azury stone melts in Samarkand (National Kazak, vol. 2).

The ceremony of house cleaning before Norouz is one of the common customs among Iranians and Kazakhs. The house-cleaning primarily denotes disintegration and then order and regulation. At past time, the home was disturbed entirely for cleaning. The houses were whitened and the yearly darkening was removed from carpets while peoples in both countries believed and may believe currently that the souls of the dead people return to their houses in this day so that they are happy if the house is clean. For this reason, in the past time and several days before New Year, people incensed musk and ambergris and lit the candle in the houses. Kazakhs argue that cleaning of house causes at the start of New Year the inhabitants of the given home not to be subjected to disaster and illness. They believe in this idea and observe it.

Similar to Iranian people, the Kazakhstan people wear new cloths and the outfit of Kazakh people is usually white cloth as a symbol of happiness. The visiting of various relatives is also done similarly in both countries in New Year.

Kazakhs serve a cuisine titled "Norouz Gujeh" in New Year and term "Gujeh” means literally as "Ash Food (soup)" in Kazakh language so serving this cuisine is deemed as farewell to winter. Upon coming New Year, the people serve rice-milk cuisine in some areas of Iran and they believe that if rice-milk is served and boiling during time of coming New Year, it is led to blessing and rising abundance and plentiful sustenance in New Year².

The ceremony of "New Year Boss" (Mir-E-Norouzi) is another rite that has been performed. In Iran several years ago and currently it is executed as well in some areas at Iran including northern regions of Iran as the habitat of Kazakhs.

This ceremony is a type of make-up chaos namely displacement of boss and peasant. The people elected recreationally a person from the social lower class as ruler in this ceremony for several days or a few hours and the temporary sultan issued some commands according some rules and then he was dismissed from position of boss.

Growing green plants, which is a symbol of blessing and abundance, is performed in Iran and Kazakhstan. In ancient Persia, the people grew three portions of wheat and barley and millet with symbols of good thought, good speech, and good conduct.

Several games and contest are held among Kazakhs in New Year Holidays such as "Qoltuzan" and "Kukpar" games. In Kukpar game, a goat should be raised from certain place by the horse-riders so this contest is popular among some Iranian tribes including Turkmens (Niknejad, 2003, p. 91).

One of ideas in which the Kazakhs believed was that they never send out pregnant women from the home and or patio and they did not leave her alone in the house. According to their paradigm, Jin and fairies come and go in such places and to handle this problem they put knife and axe under the head and knee of pregnant

\footnotetext{
${ }^{2}$ Retrieved from http://www.persian.man.ir
} 
woman. This custom has been still popular in some of Iran tribes.

It is customary among Kazakhs for a woman suffers from pain of childbirth and in order to leave away Jin and devil from her to incense juniper wood, tapping on pallet and tray, keeping horse at the front of house of the pregnant woman, shooting from gun. These customs have been performed among some Iranian tribes to leave away the enemy from the pregnant women namely "Beowulf" (Aal).

In Kazakh norm, birth of son has been deemed as luck and fortune and they express that the sun rose on someone, who bore a son. Paying attention to male child has also existed and occasionally exists as well.

The circumcision ceremony has been performed with special customs and holding feast of happiness both in Kazakhstan and Iran.

\section{References}

Askari, A., \& Kamali, M. S. (1995). Iranian Turkmen, an anthropologic research. Tehran: Asatir publications.

Christiansen, A. (1995). Iran under Sassanid. (R. Yassami, trans.). Tehran: Donyaye Ketab publications.

Dehkhoda, A. (1994). Dictionary (6 volumes). Tehran, Tehran University publications.

Gotschmit, A. V. (2000). History of Iran and its neighbors under Alexander to downfall of the Parthians. Tehran: Ghoghnoos publications.

Ghirshman, R. (1991). Iran history from the beginning to Islam. (M. Moein, trans.). Tehran: Elmi and Farhangi (Scientific and cultural) publications.

Herodotus. (2011). History. (V. Mazandarani, trans.). Tehran: Elmi and Farhangi (Scientific and cultural) publications.

Losinski, B. P. (2001). Origin of the Parthians. (R. Behzadi, trans.).

Niknejad, A. (2003). Gorgan of yesterday, Gorgan of today. Tehran: Eshgh Danesh publications.

Poormohammadali Shooshtari, A. (1942). Book of Iran (or second section of Iranians' Parthian era. Printing-House of Bank Melli Iran.

Pirnia, H. (n.d.). Iran history from the beginning to Qajar downfall. Tehran: Khayyam Publications.

Shahbazi, S. (n.d.). Great Cyrus. Shiraz: Shiraz University publications.

Yarshater, E. (1998). History of Iran from Seleucid to downfall of sassanid. (H. Anoosheh, trans.) (3rd volume). Amir Kabir publications.

Zarinkoob, A. (2003). History of Iran people, Iran before Islam. Tehran: Amir Kabir publications. 